\title{
Seasonal risk management method in agro-industrial projects
}

\author{
O. Denchyk \\ University "KROK", Kyiv, Ukraine \\ Corresponding author. E-mail: oksanadenchyk@gmail.com \\ Paper received 11.12.19; Accepted for publication 22.12.19.
}

\section{https://doi.org/10.31174/SEND-NT2019-215VII26-12}

Abstract. This scientific paper presents the method and describes the algorithm of seasonal risk management in agro-industrial projects, which was developed on the basis of the model of risk management in projects of the agro-industrial complex "4 SEASONS". Application of this tool kit will help project managers to manage more effectively the risks of agro-industrial projects and to increase the production of agricultural products, both crop and animal husbandry.

Keywords: projects, risk management, method, risk management methods, agro-industrial projects.

Introduction. Climate change is a very significant factor of many risks in agro-industrial projects. The seasonality of agricultural production is closely connected with the climatic zone of agriculture and weather conditions of the area. With ever increasing frequency farmers are realizing that change of varieties and crops to more drought resistant ones or implementation of artificial watering of fields is an inevitable strategy for the survival of agro-industrial projects. This applies not only to crop growing but also to animal husbandry. Some farmers have faced the difficulties in providing of cattle with herbage because of drought in their farming areas, so they choose to grow another animal species such as poultry or pigs. Mastery of tools of seasonal risk management will help project managers to prevent risk situations or to reduce losses from them in agricultural projects.

Review of publications on the topic. Nguyen N., Wegener M., Russell I., Cameron D., Coventry D. and Cooper I. [1] have addressed the issues of identifying risk sources in agriculture and stated that the most specific source of risk was unstable weather.

Kobylyanska O. M. [2] had been studying the impact of production risks on agricultural enterprises, Lytvynchuk I. L. [3] had been studying the economic risk management of corporate enterprises of agricultural sphere, Matviyenko $\mathrm{H}$. A. [4] had been studying the processes of insurance risk management and developed recommendations as to the improvement of their management in agricultural crop growing, Nykolyuk O. M. [5] described aspects of business risk management of hop producers.

Scientists [6, 7, 8,] proposed several classifications of risks connected with farming in agro-industrial sphere.

Moreover, there are studies with more detailed research of agricultural enterprise project management and management of risks, which may appear in the process of implementation of such projects. For example, Tymochko V. O. [9] substantiated feasibility of introducing innovative production technologies based on the cooperative use of technical means and outlined the stages of creating of a conceptual model of the project of a cluster integration of agricultural enterprises; Flys I. M. [10] analysed contemporary social, industrial and economic situation in the countryside, substantiated the necessity of scientific and methodological support for the implementation of innovative programs and projects in the agro-industrial complex of the country, and also revealed the main requirements for innovative projects in the programs of sustainable village and rural areas development; Sydorchuk O. V. [11] outlined the agro-meteorological components of the project environment, which is an unmanageable cause of technological risk at different stages of crop cultivation projects; Tryhuba A. M. [12] substantiated feasibility of risk management in the integrated agricultural production programs and identified the causes of risk in these programs and also presented relationship between the components of risk in them in an implicit way.

Danchenko O. B., Krol K. J, Denchyk O. R. [13] stated that the financial success of projects is influenced by success indexes of interaction with stakeholders, ability to build a constructive dialogue, to find mutually beneficial solutions and effectively implement them.

Krol K. J. [14] noted that success of the project depends on mastery of project management, ability to tack between the interests of stakeholders, which are often opposite. Although, definition of "success" for each case, as well as for each stakeholder, is their own. Moreover, the interests of stakeholders may change during the project and, as a result, the vision of success will change too. The issues of stakeholders interests are raised by Freeman R. E. [15] and Pedersen E. R. in their works [16]. Indeed, the most important aspects for corporations that produce (grow) food products are economic, social and environmental issues.

Agricultural project risk management also involves management of possibilities of these projects. In the studies $[17,18]$ the authors propose to use such tool as Weirich interactive matrix [19] in agricultural project management, which will help to cope with the complexity of project analysis caused by various strategic factors, to deal with different combinations of relationships and which is quite visual and easy to use.

In her study Danchenko O. B. [20] stressed the importance and advantages of skilful project risk management with application of the corresponding tool kit.

Feasibility of using the integrated risk management method for agricultural projects is described in the study [21].

Significant dependence on the seasonality in agricultural projects and necessity of development of tools to facilitate the work of project managers the author describes in the study [22].

The performed analysis of the scientific studies shows that project approach to agricultural project management is in its infancy. When conducting researches special attention should be paid to the development of tools and methods of agricultural project risk management, which relate to the seasonality of these projects.

The aim of this study is development of tools for seasonal risk management of agricultural projects. 
Materials and methods. Although uncertainty and risk are an integral part of the implementation of agro-industrial projects worldwide, diversification strategies can help to reduce risk losses.

The term diversification of agricultural products production should mean redistribution of some farming production resources such as land, machinery, capital, human resources etc. into new activities to avoid negative effects of such risks as climate variability, changeability of prices on agricultural products and many other risks [23].

Diversification of crops by means of growing of several cultivated crops significantly reduces the risks of complete loss of agricultural production and magnitude of damage caused by diseases and pests, which affect the crops, unfavorable market and weather conditions. Selecting several crops by means of crop rotation during several seasons or by mixed system in the same season, it is necessary to understand clearly, which risks may appear in your farm area considering data of previously implemented projects.

Organic diversification of crop production can be livestock production. Such projects may be deemed as synergistic/symbiotic. Application of the diversification method increases the possibility of obtaining higher and more stable farming incomes.

The main risk factors of agricultural business are the following: strategic risks, seasonality of production; dependence on weather and climate conditions; long period of capital circulation; difficulties in change of the range of products and technologies; hard limitations of the technological process in time frames; dependence on biological factors; high capital-output ratio.

Seasonality of production is tightly connected with weather conditions, which are characteristic to the climatic zone. Violation of terms and consistency, as well as the quality of technological operations, inevitably increases the risk of loss of production and income.

The author developed a model of identification for risks in agricultural projects "4 SEASONS", which became a basis for development of seasonal risks management methods in projects of agro-industrial complex.

The model of risk management in projects of the agroindustrial complex "4 SEASONS" will be useful for project managers as an instructive and convenient tool for agricultural project risk management. It is recommended for application in project planning and project implementation phases for obtaining of a maximum advantage from project capability and for development of strategies to counter potential project threats and strengthening of project weaknesses.

It is important to identify all possible risks in each agroindustrial project and to record them according to the season (spring, summer, autumn, winter) to the "4 SEASONS" model, using data from previous years. There are the following risk identification methods [20, 22]: "check-list" method, 6W1H method, brainstorming technique, decisiontree analysis, expert interviews, review, Delphi method. Of course, each agricultural project, like any other project, is unique and therefore the risks for each project will be different.

After analysis and risk assessment, it is necessary to prepare a plan of countermeasures against risks and to record them to the model. Opposite each risk there are countermeasures to combat it [20].

The process of development of a risk response plan includes avoidance, reduction, distribution and transfer with the aim to maximize opportunities and to reduce threats.

When a risk event arises, the project manager and the project team do not panic and waste no time in performing the prepared countermeasures against risk.

Results and discussion. On the basis of the conducted researches, the author proposes the seasonal risks management method in the agro-industrial projects, which includes the following stages (Fig. 1).

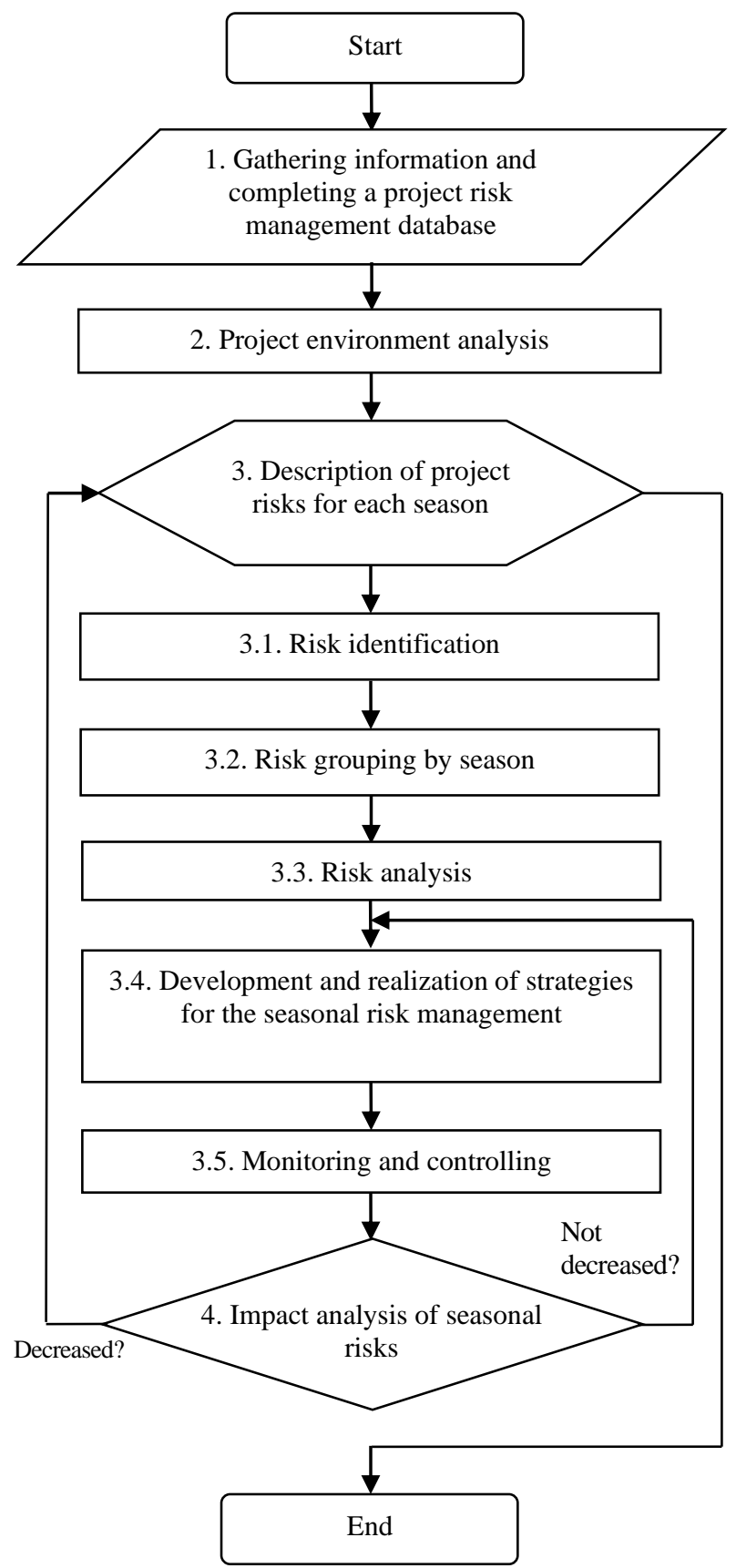

Fig. 1. The seasonal risks management method in the agroindustrial projects

1. Gathering information and completing a project risk management database. At this stage, the team of project collects, analyses and processes information of seasonal risks according to the results of previously completed projects (if any). 
2. Project environment analysis. This stage presupposes the analysis of the project environment including: revealing of seasonal risks.

3. Description of project risks for each season.

3.1. Risk identification. At this stage the project team reveals all risks that may arise during project implementation.

3.2. Risk grouping by season. Risks that may arise during project implementation are grouped according to seasons of the year.

3.3. Risk analysis. This stage involves qualitative and quantitative analysis of project risks.

3.4 Development and realization of strategies for the seasonal risk management. At this stage the project team develops strategies to prevent and avoid the occurrence of seasonal risks in the project.

3.5. Monitoring and controlling. The project team performs permanent monitoring and control of seasonal risks in order to respond to them in time.

4. Impact analysis of seasonal risks. In case of reduction, transfer to point 3 , if not reduced, return to point 3.4

Thus, the author proposes an algorithm of implementation the seasonal risks management method in the agro-industrial complex project, which is based on grouping of risks by seasons of the year and provides an opportunity to manage them more effectively and more qualitatively.

\section{ЛIТЕРАТУРА}

1. Nguyen, N., Wegener, M., Russell, I., Cameron, D., Coventry, D. \& I Cooper. Risk management strategies by Australian farmers: two casestudies, AFBM Journal, 2007, vol. 4. no. 1 \& 2, pp. 23 30 .

2. Кобилянська О.М. Виробничі ризики сільськогосподарських підприємств: автореф. дис. на здобуття наук. ступеня канд. екон. наук: спец. 08.00.04 "Економіка та управління підприємствами (за видами економічної діяльності)"/О. М. Кобилянська. К., 2011. 20 с.

3. Литвинчук I. Л. Управління економічними ризиками корпоративних підприємств аграрної сфери: автореф. дис. на здобуття наук. ступеня канд. екон. наук: спец. 08.00.04 "Економіка та управління підприємствами (за видами економічної діяльності)"/І.Л. Литвинчук. Житомир, 2010. 20 c.

4. Матвієнко Г. А. Управління страховими ризиками при вирощуванні культур в сільськогосподарських підприємствах: автореф. дис. на здобуття наук. ступеня канд. екон. наук: спец. 08.00.04 "Економіка та управління підприємствами (за видами економічної діяльності)"/Г.А. Матвієнко. Житомир, 2009. 20 с.

5. Николюк О. М. Управління підприємницькими ризиками виробників хмелю: автореф. дис. на здобуття наук. ступеня канд. екон. наук: спец. 08.00.04 "Економіка та управління підприємствами (за видами економічної діяльності)"/О. М. Николюк. Житомир, 2009. 20 с.

6. Денчик О.Р. Аналіз ризиків проектів у агропромисловому комплексі/О.Р. Денчик, Д.І. Бедрій, С.О. Савченко // Вісник ЧДТУ. Серія: Технічні науки. Черкаси, ЧДТУ, 2017. № 1. С. 100-109.

7. Kahan D. Managing risk in farming. Rome: FAO, 2008. 107 p.

8. Hurduzeu, G. The most important agriculture risk. The risk culture/Hurduzeu, G., Huidumac, C. \& Hurduzeu, R. // Proceedings of the 7th International Management Conference "New Management for the New Economy", 7-8 November 2014. Bucharest, Romania: Academy of Economic Studies, 2014. vol. 8 (1), pp. 413-418.

9. Тимочко В. О. Розробка концептуальної моделі проекту кластерного об'єднання сільськогосподарських підприємств/В. О. Тимочко, Ю. І. Ковальчик, Р. І. Падюка, О. I. Говда // Вост.-Европ. журн. передовых технологий. 2012. № 1/10. C. 60-62.

10. Флис I. М. Головні вимоги до інноваційних проектів у програмах розвитку сіл та їх територій/I. М. Флис // Вост.Европ. журн. передовых технологий. 2010. № 1/3. С. 61-63.

11. Сидорчук О. В. Вплив агрометеорологічної складової на ризик проектів вирощування сільськогосподарських культур/О. В. Сидорчук, А. М. Тригуба, П. М. Луб, А. О. Шарибура, Л. Л. Сидорчук // Вост.-Европ. журн. передовых технологий. 2012. № 1/10. С. 49-51.

12. Тригуба А. М. Формування виробничо-технологічного ризику в інтегрованих програмах аграрного виробництва/А.
М. Тригуба, П. В. Шолудько, О. В. Маланчук, М. В. Рудинець // Вост.-Европ. журн. передовых технологий. 2013. № 1/10. С. 203-206.

13. Данченко О. Б. Управління зацікавленими сторонами в проектах агропромислового комплексу/О. Б. Данченко, К. Я. Круль, О. Р. Денчик // Тези доповідей XV міжнародної конференції «Управління проектами у розвитку суспільства». Тема: Управління проектами в умовах переходу до поведінкової економіки //Відповідальний за випуск С. Д. Бушуєв. К.: КНУБА, 2018. С. 79-81.

14. Круль К. Я. Особливості управління ризиками стейкхолдерів проектів агропромислового комплексу/К. Я. Круль // Управління проектами: стан та перспективи. Матеріали XIV міжнародної науково-практичної конференції 11-14 вересня 2018 р. Миколаїв: Торуба В. В., 2018. С. 63- 64.

15. Freeman R.E. Strategic Management: A stakeholder Approach. Boston. MA: Pitman. 1984. p.276.

16. Pedersen E.R. All Animals are Equal, but...: How Managers in Multinational Corporations perceive Stakeholders and Societal Responsibilities. CBS Center for Corporate Social Responsibility. Working paper No. 05-2009. 2009.

17. Данченко О.Б. Метод управління можливостями та загрозами в проектах агропромислового комплексу/О. Б. Данченко, О. В. Коломицева, О. Р. Денчик, К. Я. Круль // Збірник наукових праць Черкаського державного технологічного університету. Серія: Економічні науки. Черкаси: ЧДТУ, 2019. Вип. 54. С. 60-65.

18. Денчик О. Р. Особливості використання інтерактивної матриці Вейріха в управлінні сільськогосподарськими проектами/О. Р. Денчик // Управління проектами: стан та перспективи. Матеріали XIII міжнародної науковопрактичної конференції 12-15 вересня 2017 р. Миколаїв: НУК, 2017. - С. 26-28.

19. Weihrich H. The TOWS Matrix a Tool for Situational Analysis, Long Range Planning. 1982. Vol. 15. № 2. pp. 54-66.

20. Данченко О.Б. Огляд сучасних методологій управління ризиками в проектах/О.Б. Данченко // Управління проектами та розвиток виробництва: Зб. наук. пр. Луганськ: вид-во СНУ ім. В.Даля, 2014. №1 (49). С. 16-25.

21. Denchyk O.R. Method of integrated risk managements for agroidustrial project/ O.R. Denchyk, K. J. Krol // Science and Education a New Dimension. Humanities and Social Sciences. 2019. VII (34). I.: 205. pp. 25-29.

22. Денчик О. Р. Особливості використання моделі «4 сезони» в управлінні ризиками в сільськогосподарських проектах/О. Р. Денчик // Управління проектами: стан та перспективи. Матеріали XIV міжнародної науково-практичної конференції 11-14 вересня 2018 р. Миколаїв: НУК, 2018. - С. 37 - 39.

23. Kisan Gunjal. Agricultural Risk Management Tools. PARM. 2016. 120p. 


\section{REFERENCES}

2. Kobylyans'ka O. M. Vyrobnychi ryzyky sil's'kohospodars'kykh pidpryyemstv. Avtoreferat Dys. [Production risks Agricultural Enterprises: Author's abstract], Kyiv, 2011, 20 p.

3. Lytvynchuk I. L. Upravlinnia ekonomichnymy ryzykamy korporatyvnykh pidpryiemstv ahrarnoi sfery. Avtoreferat Dys. [Managing economic risks corporate enterprises of agrarian sphere: Author's abstract], Zhytomyr, 2010, 20 p.

4. Matviyenko H. A. Upravlinnia strakhovymy ryzykamy pry vyroshchuvanni kultur v silskohospodarskykh pidpryiemstvakh. Avtoreferat Dys. [Management of insurance risks when growing crops in farms: Author's abstract] 2009, Zhytomyr, 20 p.

5. Nykolyuk O. M. Upravlinnia pidpryiemnytskymy ryzykamy vyrobnykiv khmeliu. Avtoreferat Dys. [Managing business risks hop producers: Author's abstract], 2009, Zhytomyr, 20 p.

6. Denchyk O. R., Bedryj D. I. \& Savchenko S. O. Analiz ry`zy`kiv proektiv v agropromy`slovomu kompleksi [Project risks analysis in agricultural sphere]. Visnyk Cherkas'koho derzhavnoho tekhnolohichnoho universytetu. Seriya: Tekhnichni nauky [Bulletin of Cherkasy State Technological University. Series: Engineering], Cherkasy, 2017, no. 1, pp. 100-109.

9. Tymochko V. O., Kovalchyk Yu. I., Padyuka R. I., Govda O. I. Rozrobka kontseptualnoi modeli proektu klasternoho obiednannia silskohospodarskykh pidpryiemstv [Development of conceptual model of the project of cluster association of agricultural enterprises]. Vost.-Yevrop. zhurn. peredovykh tekhnologiy [East European Journal of Advanced Technology], 2012, no. 1/10, pp. 60-62.

10. Flys I. M. Holovni vymohy do innovatsiinykh proektiv u prohramakh rozvytku sil ta yikh terytorii [Main requirements for innovative projects in rural development programs and their territories]. Vost.-Yevrop. zhurn. peredovykh tekhnologiy [East European Journal of Advanced Technology], 2010, no. 1/3, pp. 61-63.

11. Sydorchuk O. V., Tryhuba A. M., Lub P. M., Sharybura A. O., Sydorchuk L. L. Vplyv ahrometeorolohichnoi skladovoi na ryzyk proektiv vyroshchuvannia silskohospodarskykh kultur [Influence of agrometeorological component on risk of crop cultivation projects]. Vost.-Yevrop. zhurn. peredovykh tekhnologiy [East European Journal of Advanced Technology], 2012, no. 1/10, pp. 49-51.

12. Tryhuba A. M., Sholudko P. V., Malanchuk O. V., Rudynets M. V. Formuvannia vyrobnycho-tekhnolohichnoho ryzyku v intehrovanykh prohramakh ahrarnoho vyrobnytstva [Formation of production and technological risk in integrated programs of agricultural production]. Vost.-Yevrop. zhurn. peredovykh tekhnologiy [East European Journal of Advanced Technology], 2013, no. 1/10, pp. 203-206.
13. Danchenko O. B., Denchyk O. R., Krol K. J. Upravlinnia zatsikavlenymy storonamy $\mathrm{v}$ proektakh ahropromyslovoho kompleksu [Stakeholder management in agroindustrial projects]. Tezy XV mizhnarodnoyi konferenciyi "Upravlinnya proektamy` $\mathrm{u}$ rozvy`tku suspil`stva". Tema: Upravlinnia proektamy v umovakh perekhodu do povedinkovoi ekonomiky [Proceeding of the 15th International Conference "Project management in the development of society". Subject: Project management in a transition to a behavioral economy], Kyiv, 2018, pp. 79-81.

14. Krol K. J. Osoblyvosti upravlinnia ryzykamy steikkholderiv proektiv ahropromyslovoho kompleksu [Features of stakeholder risk management of agroindustrial projects]. Materialy XIV mizhnarodnoi naukovo-praktychnoi konferentsii "Upravlinnia proektamy: stan ta perspektyvy" [Proceeding of the 14th International Scientific and Practical Conference "Project management: Status and Prospects"], Mykolaiv, 2018, pp. 63 64.

17. Danchenko O. B., Kolomytseva O.V., Denchyk O. R., Krol K. J. Metod upravlinnia mozhlyvostiamy ta zahrozamy v proektakh ahropromyslovoho kompleksu [The method of risks and opportunities management in the projects of agroindustrial complex]. Zbirnyk naukovykh prats Cherkaskoho derzhavnoho tekhnolohichnoho universytetu. Seriia: Ekonomichni nauky [Proceedings of Scientific Works of Cherkasy State Technological University. Series: Economics], Cherkasy, 2019, I.: 54 , pp. $60-65$.

18. Denchyk O.R. Osoblyvosti vykorystannia interaktyvnoi matrytsi Veirikha $\mathrm{v}$ upravlinni silskohospodarskymy proektamy [Features of the use of the Weirich's interactive matrix in agricultural project management]. Materialy XIII mizhnarodnoi naukovopraktychnoi konferentsii "Upravlinnia proektamy: stan ta perspektyvy" [Proceeding of the 13rd International Scientific and Practical Conference "Project management: Status and Prospects"], Mykolaiv, 2017, pp. 26 - 28.

20. Danchenko O. B. Ohlyad suchasnykh metodolohiy upravlinnya ryzykamy $\mathrm{v}$ proektakh [Overview of modern risk management methodologies in projects]. Upravlinnya proektamy ta rozvytok vyrobnytstva: zb. nauk. pr. [Project management and development of production: Collection of Scientific Publications], 2014, no. 1 (49), pp. 16-25.

22. Denchyk O. R. Osoblyvosti vykorystannia modeli «4 sezony» v upravlinni ryzykamy v silskohospodarskykh proektakh [Features of the use of the "4 seasons" model in risk management in agricultural projects]. Materialy XIV mizhnarodnoi naukovopraktychnoi konferentsii "Upravlinnia proektamy: stan ta perspektyvy" [Proceeding of the 14th International Scientific and Practical Conference "Project management: Status and Prospects"], Mykolaiv, 2018, pp. 37-39. 